\title{
Moving beyond fitting fish into equations: Progressing the fish passage debate in the Anthropocene
}

Birnie-Gauvin, Kim; Franklin, Paul; Wilkes, Martin ; Aarestrup, Kim

Published in:

Aquatic Conservation: Marine and Freshwater Ecosystems

Link to article, DOI:

10.1002/aqc.2946

Publication date:

2018

Document Version

Peer reviewed version

Link back to DTU Orbit

Citation (APA):

Birnie-Gauvin, K., Franklin, P., Wilkes, M., \& Aarestrup, K. (2018). Moving beyond fitting fish into equations:

Progressing the fish passage debate in the Anthropocene. Aquatic Conservation: Marine and Freshwater Ecosystems, 29(7), 1095-1105. https://doi.org/10.1002/aqc.2946

\section{General rights}

Copyright and moral rights for the publications made accessible in the public portal are retained by the authors and/or other copyright owners and it is a condition of accessing publications that users recognise and abide by the legal requirements associated with these rights.

- Users may download and print one copy of any publication from the public portal for the purpose of private study or research.

- You may not further distribute the material or use it for any profit-making activity or commercial gain

- You may freely distribute the URL identifying the publication in the public portal 


\section{Anthropocene}

5

6

7

Accepted in Aquatic Conservation (supplemental issue: Freshwater Ecosystems in the Anthropocene)

9

Kim Birnie-Gauvin ${ }^{1}$, Paul Franklin ${ }^{2}$, Martin Wilkes ${ }^{3}$ and Kim Aarestrup ${ }^{1}$

12

${ }^{1}$ Section for Freshwater Fisheries and Ecology, National Institute of Aquatic Resources,

Technical University of Denmark, Vejlsøvej 39, 8600 Silkeborg, Denmark

${ }^{2}$ National Institute of Water and Atmospheric Research, Gate 10 Silverdale Road, Hamilton,

New Zealand

${ }^{3}$ Centre for Agroecology, Water and Resilience, Coventry University, Ryton Organic

Gardens, Wolston Lane, Ryton-on-Dunsmore, United Kingdom, CV8 3LG

19

Author for correspondence: K. Birnie-Gauvin, kbir@aqua.dtu.dk 


\section{Abstract}

27

1. Realization of the importance of fish passage for migratory species has led to the development of innovative and creative solutions to mitigate the effects of artificial barriers in freshwater systems in the last few decades ('fishways').

2. In many instances, however, the first move has been to attempt to engineer a solution to the problem, thus attempting to "fit fish into an equation”. These fishways are often derived from designs targeting salmonids in the Northern Hemisphere. They are rarely adequate, even for these strong-swimming fish, and certainly appear to be unsuitable for most other species, not the least for those of tropical regions.

3. Fishway design criteria do not adequately account for natural variation among individuals, populations and species. Moreover, engineered solutions cannot reinstate the natural habitat and geomorphological properties of the river, objectives that have been largely ignored.

4. Here, we discuss the most prominent issues with the current management and conservation of freshwater ecosystems as it pertains to fish passage. This paper is not intended as a review on fish passage, but rather a perspective paper on the issues related to fishways, as seen by practitioners.

Keywords: biodiversity, conservation, dams, ecological engineering, habitat, hydropower, fishways, freshwater, management, weirs 


\section{Introduction}

52

Fragmentation of freshwater ecosystems has been identified as one of numerous global river syndromes characteristic of the Anthropocene (Meybeck, 2003). Continued human population growth will only serve to increase pressures on water resources, driving further investment in infrastructure to support water, food and energy security, and to protect land and property from flooding (Vörösmarty et al., 2010; Garcia-Moreno et al., 2014). For example, at least 3,700 major hydropower dams (capacity >1MW) are planned or under construction worldwide, and the number of smaller dams $(<1 \mathrm{MW})$ planned is likely to significantly exceed this (Zarfl, Lumsdon, Berlekamp, Tydecks, \& Tockner, 2015).

While ensuring access to food, energy and potable water is fundamental for supporting the future of human societies, freshwater biodiversity in the Anthropocene is under great threat due to unsustainable river basin development (Vörösmarty et al., 2010; Garcia-Moreno et al., 2014; Poff, 2014). Ongoing river fragmentation and dam construction presents one of the greatest global threats to freshwater biodiversity and ecosystem functioning (Dudgeon et al., 2006). Disruptions to river connectivity threaten ecosystem structure and function by interrupting movements of migratory species (Winemiller et al., 2016), blocking the exchange of individuals and genetic information between populations (Wofford, Gresswell, \& Banks 2005; Raeymaekers et al., 2008), modifying aquatic habitats and altering flow and sediment transport regimes (Bunn \& Arthington, 2002). Unfortunately, consideration of biodiversity and ecosystem functioning tends to take a distant second place to engineering solutions that meet immediate human needs (Garcia-Moreno et al., 2014). This is despite the increasing recognition that biodiversity loss impairs and fundamentally alters the functioning of ecosystems upon which society depends for food, energy and water security (Vignieri, 2014). 

culturally important fisheries (e.g. Winemiller et al., 2016). As a result, the loss of fish populations during the Anthropocene has probably received greater global attention than any

other freshwater group. Connectivity is fundamental to the structure and functioning of freshwater fish communities and aquatic ecosystems worldwide, and is active along the longitudinal, vertical, lateral and temporal dimensions (Tockner, Schiemer, \& Ward 1998). Instream structures, such as dams, weirs, tide gates and culverts, interrupt connectivity in all dimensions, with the repercussions being observed as species and/or population declines and extirpations in river systems across the globe (Table 1 ).

The impact of instream structures on the movements and migration of fish has long been recognized. In Northern Europe, fishways were already being established by the mid18th century. Though these early fishways were inefficient (Francis, 1870), their presence indicates the recognition of connectivity issues. At that time, the main concern was the upstream passage of Atlantic salmon, Salmo salar, mostly due to its high economic and recreational value (Katopodis \& Williams, 2012). Despite the ever-increasing awareness of barrier impacts on other fish species (Raeymaekers et al., 2008; Perkin et al., 2015; Branco, Amaral, Ferreira, \& Santos, 2017; Wilkes, McKenzie, \& Webb, 2018), contemporary approaches to fish passage research and management continue to be dominated by salmonidcentric methods, solutions and thinking, and continue to focus on the upstream passage of fish at larger structures, giving relatively little attention to equally important downstream movements and small structures.

Increasing realisation of the importance of effective fish passage for sustaining migratory species has led to the development of innovative and creative solutions to mitigate the effects of artificial barriers in freshwater systems over recent decades, but management of fish passage continues to be dominated by an 'impair-then-repair' approach (Vörösmarty, 
Pahl-Woslt, Bunn, \& Lawford, 2013). For most dams and other instream infrastructure, fishways continue to be considered an add-on 'fix' once the standard structural design is complete (Katopodis \& Williams, 2012). Furthermore, fish passage tends to be treated on a site-by-site basis, focused only on getting fish from one side of the structure to the other, and effectiveness monitoring is often absent. Rarely is consideration given to the broader catchment context of fish passage, or the impacts on aquatic habitats and ecosystem processes (Pelicice \& Agostinho, 2008; Pompeu, Agostinho, \& Pelicice, 2012; McLaughlin et al., 2013; Kemp, 2016; Silva et al., 2018). We argue that this reductionist approach is symptomatic of the origins of fish passage research, embedded in a philosophy of engineering our way out of the problems created by human modifications of the riverscape.

A characteristic of the dominant engineering approach to fish passage is determinism (e.g. 'the species can swim at $x$ velocity for $t$ time'). A general failure to consider the bigger picture and a continued focus on trying to 'fit fish into equations' cannot account for the natural variation among individuals, populations and species that is an essential characteristic of sustainable aquatic ecosystems. We believe that to improve outcomes for freshwater biodiversity, fish passage research and its applications must embrace this natural variability. To achieve this there is a need to confront what we view as inherent biases in fish passage research, policy and practice that derive from the overwhelming dominance of research on the salmonid species of the temperate Northern Hemisphere. The field of fish passage as a whole needs rethinking, with the objective of helping fish move up and down rivers with no adverse effects.

The intent of this paper, therefore, is to contribute to the ongoing debate on fish passage (e.g. Bunt, Castro-Santos, \& Haro, 2016; Kemp, 2016; Williams \& Katopodis, 2016; Silva et al., 2018) by providing a perspective on what we view to be among the most crucial issues related to the prevailing paradigm of fish passage research and management at a global 
scale. In particular, we consider the question of whether the current approach to the fish passage problem is fit-for-purpose and suitable for effectively tackling the freshwater biodiversity crisis of the Anthropocene. We finish by proposing some potential approaches to progress the fish passage debate by moving beyond some of the biases we identify, and pursuing a more holistic approach to fish passage research and applications.

\section{Biases in fish passage research and application}

\subsection{Long standing focus on salmonids and upstream passage}

Much of the knowledge we have about the effects of instream barriers, fishways, and the ability of fish to pass them is derived from studies based on anadromous salmonids in the temperate Northern Hemisphere. This focus emerged due to the well-documented declines in salmonid stocks in river systems around the globe arising from anthropogenic interruptions to migration routes (e.g. Yeakley, Maas-Hebner, \& Hughes, 2014). Due to the economic and cultural importance of salmonid populations, and often supported by local legislative requirements, efforts to 'fix' the problem emerged. Despite these efforts, there remains a focus on upstream movements, with less consideration given to getting fish back downstream (though efforts to address downstream movement have risen in recent years, e.g. Arnekleiv, Kraabøl, \& Museth, 2007; Birnie-Gauvin, Candee et al. in press).

Adult salmonids have very particular needs given their highly directed and relatively synchronized migration. Salmonid migratory behaviours are some of the most studied, though downstream movements have received considerably less attention. The behaviour of downstream migrating salmonid smolts is often simplified and believed to be addressed by designing screens and bypasses that screen fish only near the water surface (Arnekleiv et al., 2007). In our experience however, a significant proportion of smolts move below the screen, 
with evidence of individuals migrating near the bottom (Svendsen, Eskesen, Aarestrup, Koed, \& Jordan, 2007). Our lack of focus (and knowledge) on this downstream movement, combined with the observation of highly synchronous upstream migrations, have led to the perception that these fish have relatively narrow and well-defined needs, with characteristics that suit the reductionist approach of the engineering discipline.

Historically, designing effective fish passage solutions was challenged by the constraints (primarily space, cost and flow) typically imposed by having to retrospectively append fishways to existing structures. Solutions inevitably became a balancing act between overcoming the fall height created by the obstruction, minimising fishway length, and maintaining hydraulic conditions in the fishway within the capabilities of the target species and life stage, and only generating marginal changes to the function of the obstacle in question. Adult salmonids are agile and highly capable swimmers as they swim upstream and, thus, have a greater ability to overcome more hydraulically challenging environments than many other species. This has had a strong influence on the type and hydraulic performance standards of most fishway designs that exist today (Mallen-Cooper \& Brand, 2007).

Fish passage research remains largely entrenched in the early paradigm of salmonid biology. This long-standing focus has resulted in the same approach being perpetuated all over the globe, for all species, in all geographical contexts, rather than taking a step back and rethinking whether it is the right approach in a particular location (e.g. Link \& Habit, 2015; Mallen-Cooper \& Brand, 2007; Wilkes et al. in press). Despite the significant differences between the requirements of salmonids and most other fishes (e.g. Figure 1), including those from the tropics and temperate Southern Hemisphere, the knowledge, techniques, thinking and solutions developed from studies of salmonids have been widely transferred to fish passage design and management elsewhere (Silva et al., 2018). Application of these 
approaches to freshwater systems with native species that have completely different needs has contributed to repeated failures and poor performance of fishways around the world (Lira et al., 2017; Wilkes et al., 2018). For example, Mallen-Cooper and Brand (2007) showed very poor passage of native Australian fish species through a salmonid fishway on the Murray River, with $<1 \%$ of the most abundant species ascending. The continued underwhelming performance of many salmonid fishways (Brown et al., 2013), and ongoing unsuccessful application of salmonid-centric solutions to non-salmonid species has led some to suggest that, in a global sense, fishways are a technology in decline (Kemp, 2016).

\subsection{Engineering our way out of the problem}

The fundamental dichotomy of the fish passage problem is the need to balance the trade-offs between doing what would be best ecologically (i.e. remove all barriers), and trying to engineer our way out of the problem where there is a need for essential infrastructure (e.g. Nieminen, Hyytiäinen, \& Lindroos, 2017). In too many instances, engineered solutions continue to be the default first step to solving fish passage issues. We suggest this bias has emerged from the emphasis of early fish passage research on retrospectively engineering site scale solutions to fix problems for individual species at existing infrastructure. This has embedded the idea of fish passage solutions as an 'add on' to structural designs, rather than an integral component of the design to be considered from the outset. However, inappropriate transfer of technological solutions and increasing evidence of the unintended consequences of providing fish passage (Pelicice \& Agostinho, 2008; McLaughlin et al., 2013; Pelicice, Pompeu, \& Agostinho, 2015), along with the broader ecosystem changes (Birnie-Gauvin, Aarestrup, Riis, Jepsen, \& Koed, 2017), raise questions over the continued suitability of this approach. 

there will always be cases where engineered solutions are required. However, current design philosophies tend to force ecologists to take a reductionist approach, trying to fit fish into equations suitable for engineers to work out a solution that fits the appropriate hydraulic design envelope and minimizes costs. This approach has undoubtedly contributed to the less than satisfactory success of many fish passage solutions, as evidenced in multiple reviews (Roscoe \& Hinch, 2010; Bunt, Castro-Santos, \& Haro, 2012; Noonan, Grant, \& Jackson, 2012; Lira et al., 2017). The simplified representations of reality required by this approach, while convenient, inevitably fail to capture the natural variation that is characteristic of all organisms, ecological communities and ecosystems. Furthermore, the ability to effectively characterise the full range of hydraulic requirements of multiple species and life stages of fish in sufficient detail to provide effective hydraulic design criteria is impractical, particularly when considering 'megadiverse' fish communities such as those typical of tropical regions (Winemiller et al., 2016).

We encourage a more holistic approach, planning infrastructure and designing structures from the outset with a view to maintaining ecosystem processes and functioning, including aiming for the seamless movement of organisms. Doing so requires a change in design philosophy and a shift in expectations of how things should be done at every level. Scientists, engineers and managers must realise that the difference between removing (or not installing) a barrier and constructing a fishway is huge; fishways will never be as effective as the complete absence of barriers for providing fish with sufficient habitat and allowing safe movement. We argue that the first question we should always ask ourselves (perhaps twice) is whether that barrier is necessary at all, and if so, whether a fishway will contribute to the maintenance of viable populations upstream and downstream of the structure (e.g. Pompeu et al., 2012). There is strong evidence that removing artificial barriers to migration can be cost- 
effective and result in rapid recovery of freshwater biodiversity and ecosystem processes, as seen for American eel (Anguilla rostrata; Hitt, Eyler, \& Wofford, 2012), sea lampreys (Petromyzon marinus; Hogg, Coghlan, \& Zydlewski, 2013), brown trout (Salmo trutta; Birnie-Gauvin, Larsen, Nielsen, \& Aarestrup, 2017; Birnie-Gauvin, Candee et al. in press) as well as other species (O’Connor, Duda, \& Grant, 2015;), yet barrier removal remains relatively uncommon, even where structures are redundant. Consequently, despite the growing use of fishways, which are supposedly designed to allow migrating fish to bypass barriers and reach suitable habitat in which to grow and reproduce, these structures remain mere pacifiers of the underlying ecological problems (Roscoe \& Hinch, 2010; Bunt et al., 2012, 2016; Noonan et al., 2012; Lira et al., 2017).

\subsection{Requirement mismatches and ignoring natural variation}

The dominance of salmonid studies and reductionist engineering design approaches have combined to result in a situation where consideration of natural variations in fish behaviour and dispersal capabilities are minimised. Migration is a concept which has been known and studied for centuries. Its occurrence is widespread across all major taxonomic groups and has piqued the interest and curiosity of scientists for as long as it has been known. For decades, we have tried to understand its underpinning mechanisms and drivers, making a point of protecting migratory species as they usually depend on at least two types of environments to thrive (e.g. eels growing in freshwater and migrating to saltwater to spawn). While many of the overarching concepts of migration are well known, and largely accepted, the focus on a relatively narrow range of high status species has biased management actions towards particular life history strategies. Furthermore, it has led us to stop questioning some of the basic information we have regarding migration. 
life histories. However, even within the well-studied salmonid species, there is growing

evidence that salmonid smolt migrations occur throughout the year rather than during a single

Gauvin, \& Larsen, 2018). Despite this, current fish passage management strategies, such as

spillway opening and dam/weir closure periods, typically only occur during the peak spring

Another important consideration is the 'migratory' versus 'non-migratory' or

'resident' terminology; it creates the perception that non-migratory or resident fish do not move, yet they do (Schlosser \& Angermeier, 1995; Jepsen \& Berg, 2002; Radinger \& Wolter, 2014), and they may be impacted by barriers more than is traditionally recognised (e.g.

Branco et al., 2017). The whole fish passage issue has largely focused on obligate migrants, sometimes classifying facultative migratory species as non-migratory for the purpose of passage needs. The functional explanations for movement of 'non-migratory' or 'resident' fish are manifold, and may involve distances of the same order of magnitude to those characteristic of 'migratory' species. The reasons include: (i) to avoid unpredictable resource scarcity and perturbances (e.g. Falke, Fausch, Bestgen, \& Bailey, 2010); (ii) to repopulate habitats previously affected by disturbance or disease (e.g. Perkin et al., 2015); (iii) to shift distribution gradually in response to large-scale environmental change, including climate change (Hari, Livingstone, Siber, Burkhardt-Holm, \& Guttinger, 2006); and (iv) to exchange adaptive genetic information in the face of environmental change (e.g. Brauer, Hammer, \& Beheregaray, 2016). We stipulate unpredictability in some of the instances listed above

271 because if the phenomena were predictable the species may well be considered migratory.

272 Such 'unpredictability' also encompasses the effects of climate change, so movement for 
resident fish is likely to become even more important. There is a need in the first instance, therefore, to recognise this diversity of movements that occur within and between species and over time, and to cater for this diversity of movements in fish passage research and applications. There is also a need to consider variation at the individual level.

Individuals vary in their ability and motivation to overcome barriers (Agostinho et al., 2007; Bunt et al., 2012). There also exists variation amongst populations of the same species (Birnie-Gauvin, Larsen, Thomassen \& Aarestrup, 2018; Figure 1). The reductionist approach typically adopted for fishway design means that this natural variation is often neglected completely, or is at least poorly accounted for (but see Wilkes et al. in press). Variation in fish behaviour and requirements is wide-ranging, and often discounted in modelling exercises, potentially rendering the outcomes invalid when we apply them to real-life situations. Whilst modelling is a valuable tool, explicit considerations of the uncertainty created by natural variation need to be implemented. Most modelling approaches in fish passage research, at their core, are equations. This means that fish must be fitted into a mathematical phrase, essentially collapsing all natural variation into one 'magic’ number, even in situations where swimming behaviour between populations is strongly divergent (e.g. Link et al., 2017). Whilst the biologist would be calling for explicit recognition of this divergent swimming behaviour in fishway design, the engineer may instead consider an equation that does away with this variability.

The requirement to fit fish into equations in a way that is consistent with typical engineering design practices has seen an emphasis on efforts to quantify fish swimming speeds. The most convenient way of achieving this is through controlled laboratory swimming tests. Water velocity design criteria for fishways are typically determined through controlled swimming tests that force fish to swim at a fixed mean velocity (endurance tests) or at an incrementally increasing velocity (critical swimming tests) (Beamish, 1978). While 
practical, this raises several issues related to individual variability, for example: turbulence and fish acceleration and deceleration are often ignored (but see e.g. Plew, Nikora, Larned, Sykes, \& Cooper, 2007); the difference between different measures of swimming performance remains unclear (Peake, 2004); variations in swimming performance at different temperatures or under varying water quality are often not considered (but see e.g. Bannon \& Ling, 2003); and species and individuals that do not 'cooperate' by swimming in the laboratory are often selected out rather than being considered a separate behaviour class to be accounted for (e.g. Santos, Pompeu, \& Martinez, 2007). Furthermore, the behaviour of fish in an artificial laboratory set-up is unlikely to be natural due to the stress of handling and the change in behaviour that comes with being held in captivity for long periods, as well as the absence of natural environmental heterogeneity or migration cues (e.g. Vrieze, Bjerselius \& Sorensen, 2010). This has led some authors to suggest that volitional swimming speed tests, for example measured in open channel flumes, are more appropriate (Haro, Castro-Santos, Noreika, \& Odeh, 2004). However, while this may improve the biological realism of fish swimming performance evaluations, it still does not overcome the challenge of effectively characterising the natural variability in performance between individuals and populations and translating them in to practical design criteria that account for this uncertainty. While general relationships between hydraulics and swimming behaviour can be investigated, and are essential for supporting development of hydraulic design criteria, laboratory studies alone are insufficient for developing absolute criteria and much greater effort should be placed on incorporating natural variation and uncertainty into results.

As attention in fish passage research begins to move towards catering for multispecies assemblages, a further challenge emerges in trying to also account for the variation between and among species and life stages. In all but the most extreme cases, fish passage must be available for more than a single species, each with potentially different requirements, 
at different life stages. How can we accommodate the range of individuals that must overcome barriers? A mature female on her way to spawn is full of eggs. Are her swimming abilities reduced? How can fish passage infrastructures accommodate her?

\subsection{Ignoring small-scale barriers}

The impacts of large dams have been well documented and have often been the primary focus of fish passage research. However, in most river basins, small-scale structures such as weirs and culverts frequently make up the vast majority of obstructions (Gibson, Haedrich, \& Wernerheim, 2011). Small structures, with fall heights as little as $50 \mathrm{~mm}$, can be a complete barrier for some fish species (Baker, 2003), particularly the small-bodied species characteristic of many Southern Hemisphere fish communities (Link \& Habit, 2015). Despite their widespread distribution, these smaller barriers continue to receive relatively little attention, as individually they are often deemed to have small effects (Branco et al., 2017). However, there is increasing evidence of their impacts on fish movements (Lucas, Bubb, Jang, Ha, \& Masters, 2009; Branco et al., 2017), and it has been suggested that the cumulative effects of multiple barriers can be at least as severe as large dams (Cooke et al., 2005).

Fish passage through culverts has received some attention, again focussed almost exclusively on salmonids. Early work investigated the hydraulic effects of culvert baffling (Rajaratnam, Katapodis, \& Lodewyk, 1988; Ead, Rajaratnam, \& Katapodis, 2002), and more recent studies have included observations of fish behaviour during culvert passage (Goerig, Bergeron, \& Castro-Santos, 2017). However, there is a need to develop solutions appropriate to the target species. For example, David, Tonkin, Taipeti, \& Hokianga (2014) investigated a novel approach for facilitating upstream passage of small-bodied fish through culverts using mussel spat ropes as a baffling media, showing that culvert passage success could be 
significantly improved. We suggest that increased focus on fish passage at small-scale structures has the potential for rapid and cost-effective biodiversity gains. For example, there are several studies from Australia and New Zealand describing positive outcomes for nonsalmonid fish species richness and abundance resulting from retrofitting fish passage solutions to culverts (David \& Hamer, 2012; Franklin \& Bartels, 2012; Amtstaetter, O'Connor, Borg, Stuart, \& Moloney, 2017). Erkinaro, Erkinaro, \& Niemelä (2017) also demonstrated increases in the distribution of juvenile Atlantic salmon following the restoration of impassable road culverts in Finland. However, these approaches remain embedded in the philosophy of trying to engineer a fix to be applied to a structure rather than taking a more holistic approach to fish passage management.

We suggest that, more importantly, small-scale barriers also offer the best opportunity for overcoming the bias towards engineered fish passage fixes. Many small-scale structures are now redundant, no longer serving their original purpose, but are seen as valuable parts of cultural heritage. There are obvious opportunities for removal here yet fish passage frequently takes a back seat to cultural interests. Very often, the basis of local arguments that can be observed or noticed in some way (e.g. the sound of a waterfall, a bridge over a dam, or a reservoir) win over the problems that cannot be seen by the naked eye (i.e. the fish). But what benefits are conferred from enjoying the sound of a waterfall? Should these arguments take precedence over the protection of freshwater biodiversity? The sad reality is that in the case of small barriers, these arguments will often hold. Removal of such barriers is often achievable and cost-effective, and should be a priority for achieving rapid, sustained recovery of freshwater communities (though we acknowledge that dams can sometimes serve as a barrier to the spread of non-native species; Gangloff, 2013). Removal also has the advantage of restoring physical habitat and ecosystem processes (Birnie-Gauvin, Aarestrup et al., 2017; 
Birnie-Gauvin, Tummers, Lucas, \& Aarestrup, 2017; Timm, Higgins, Stanovick, Kolka, \& Eggert, 2017).

Under circumstances where removal is not an option, it is also feasible and practicable to rethink design approaches to better accommodate the unhindered movement of organisms and maintain ecosystem processes. A good example has been the adoption of the stream simulation approach to culvert design (Forest Service Stream-Simulation Working Group, 2008). The stream simulation approach adopts a more holistic method with the objective of maintaining continuity of physical habitat and ecosystem processes between the upstream and downstream reaches. As such, the conditions inside the culvert replicate adjacent stream reaches and represent no greater impediment to the movement of organisms than progress through the normal stream environment. Studies of culverts built using this approach indicate that not only do they provide effective fish passage, but they are also more effective at maintaining sediment transport (Timm et al., 2017), and are more resilient to large flood events than traditional hydraulic culvert designs (Gillespie et al., 2014; Barnard, Yokers, Nagygyor, \& Quinn, 2015). It has also been shown that the relatively modest increases in initial investment to implement stream simulation designs can yield substantial societal and economic benefits in the long term (Gillespie et al., 2014).

\subsection{More than just safe passage: Critical habitat availability and distribution}

Barriers have received so much attention largely because they hinder the movements of fish by reducing connectivity (Wheeler, Angermeier, \& Rosenberger, 2005), and also because they alter hydrological and thermal processes (Bergkamp, McCartney, Dugan, McNeely, \& Acreman, 2000). However, the modification and loss of aquatic habitats caused by the presence of barriers is an impact that is often neglected (Franklin \& Hodges, 2015; BirnieGauvin, Aarestrup et al., 2017). Whilst the knowledge that habitat alterations are in fact 
induced by barriers is common, addressing the implications of losing ecologically-relevant habitat is rare. Because dams are most often established in river reaches with high-gradient, there can be a disproportionate loss of rheophilic (i.e., fast-flowing and highly-oxygenated water) habitat. These areas are essential for rheophilic fish species such as salmonids and eels that depend on these 'critical habitats' to complete their life-cycles. Consequently, even if those species can overcome a barrier, population viability is still compromised due to the loss of adequate habitat (Birnie-Gauvin, Aarestrup et al., 2017). Tide gates also have a significant impact on physical habitats, reducing hydrological exchange and interrupting natural salinity gradients, in addition to blocking fish movements (Boys, Kroon, Glasby, \& Wilkinson, 2012; Franklin and Hodges, 2015). Fish survival is also severely reduced due to habitat modifications. Large predatory species, such as the pike (Esox lucius), can thrive in impoundments, with younger fish as a source of food (Jepsen, Aarestrup, Økland, \& Rasmussen, 1998). Habitat loss should, therefore, be addressed through hydrological and morphological mitigation, either before or simultaneously (at the very least) with the issue of fish passage (Birnie-Gauvin, Aarestrup et al., 2017).

The complexity of the fish passage problem in Neotropical South America, Southeast Asia and Africa, reflecting the diversity of native species assemblages and the wide range of fish life-histories there, has highlighted the need to consider the distribution of critical habitats on either side of a barrier (Pompeu et al., 2012). This broader approach was necessary because fishways were found to be failing as a conservation tool; high percentages of fish approaching the fishway were passing only to be 'trapped' without access to critical habitats upstream due to reservoirs or the presence of other barriers without fishways (Pelicice \& Agostinho, 2008; Pelicice et al., 2015). In Brazil, therefore, far from protecting fish populations, policies that require the provision of fish passage at dams have in some cases been the main threat to their viability (Pelicice et al., 2017). 


\subsection{Lack of post-implementation monitoring: how well does it work?}

In many cases, monitoring the effectiveness of fishways is not implemented or is not a

licencing requirement. In other words, asking how well it works is not part of fulfilling requirements, and thus post-implementation monitoring remains unaccomplished. This is a major reason for the unsustainable policies prevailing in Brazil, as introduced in the previous example (Pelicice et al., 2017), and likely many other parts of the world. Part of the answer to this paradox relates to the deterministic tradition of engineering, as we have previously discussed. If the effectiveness of fishways is pre-determined, monitoring and adaptive management is optional. There is rarely a statutory obligation to prove that the fishway is really achieving its overall goal of sustaining viable fish populations, although it may be achieving other goals, such as those associated with corporate social responsibility. However, what difference does it make to have measures in place for fish passage if you do not know the answer to how many individuals get through and whether that is sufficient to sustain fish communities?

Herein lies a critical challenge for both fish passage scientists and practitioners; how do we define objectives for fishways (or more broadly for maintaining connectivity) that are ecologically meaningful, but are also practical (i.e. specific and measurable)? The lack of post-implementation monitoring is a lost opportunity. Understanding how existing mitigation efforts work and do not work may offer significant learnings that will help improve future rehabilitation efforts (Birnie-Gauvin, Tummers et al., 2017). However, to achieve this there is a need to provide guidance on what to monitor and how, and this is reliant on having clearly defined objectives. Definitions such as ‘effective’ or ‘free’ fish passage can be ambiguous, open to interpretation and/or unachievable. The term 'free', for example, is frequently used to describe fish passage targets, but this is highly unlikely to be measurable given the general 
lack of knowledge on how many fish attempted to pass versus how many fish actually passed a structure. Furthermore, the term "free" would require that fish are not delayed, which is seldom the case. Delay may in fact have carryover effects that may lead to future adverse consequences (McCormick, Lerner, Monette, Nieves-Puigdoller, Kelly, \& Björnsson, 2009). So can fish passage ever be free? Yes, if the barrier is removed, but no if a fishway is present. Perhaps the correct scientific question to ask is thus "How many individuals who attempt to pass actually pass?” Along similar lines, the appropriate management question to ask may be "How many individuals need to get through to meet ecological objectives and ensure population viability?” Despite their necessity in the context of fish passage, these questions are almost never inquired, let alone answered. Instead there is almost invariably a focus on the movement of individual fish in the immediate vicinity of the structure to be passed. This focus is made possible through the use of biotelemetry, which has emerged as the 'gold standard' in fish passage research (Bunt et al., 2012; Silva et al., 2018). Use of these used in biotelemetry studies has broadened the size range of fish to which this technology can community and all life stages.

470

\section{Discussion}


472 Awareness of the impacts of instream infrastructure on fish movements, and hence fish 473 populations, has increased considerably over the last couple of decades. Despite this, the reductionist, salmonid-centric, impair-then-repair approach to infrastructure design largely continues to prevail, and continues to be biased towards upstream movement. We suggest that this stems from the roots of fish passage research emerging from attempts to retrospectively engineer fishways as fixes for moving individual iconic species upstream at existing infrastructure to mitigate for an emerging problem. While we acknowledge the significant progress that has been made in restoring fish passage following this approach, including the benefits of studying salmonids in this context, the effectiveness of many of these structures remains too small to be ecologically meaningful. For example, several recent meta-analyses have attempted to evaluate the effectiveness and performance of fishways (Roscoe \& Hinch, 2010; Bunt et al., 2012; Noonan et al., 2012). The most consistent messages that emerge from these reviews are the overwhelming dominance of studies focusing on anadromous salmonids, and the high variability (ranging from near 0 to near $100 \%)$ in fishway performance. As focus has increasingly turned to non-salmonid fishes and catering for multi-species assemblages in fishways, evidence of failures in the current fish passage paradigm continues to mount. Largely precipitated by the direct transfer of findings from the Northern Hemisphere to diverse geographical and ecological contexts, repeated failures and the emergence of unintended consequences has undermined confidence and the willingness of practitioners to invest in implementing fish passage solutions (Harris, Kingsford, Peirson, \& Baumgartner, 2016). While potentially disheartening, we believe that this reflects a failure in the discipline to adequately recognise and move beyond inherent biases in methods and ways of thinking, rather than a flaw in the concept of fish passage itself. We are encouraged by recent contributions to the fish passage debate, particularly emerging from the Southern Hemisphere 
and the tropics, which challenge some of these biases. Pompeu et al. (2012), for example, propose that fishway efficiency should be assessed based on the capability of the structure to maintain viable fish populations, rather than a simple metric of the proportion of fish that ascend a structure. Traditional passage efficiency metrics may have been suitable for species similar to salmonids that exhibit relatively synchronous, seasonal and highly directed movements between clearly separated critical habitats (Kemp, 2016), but transferring these metrics to species and populations with more diverse life-histories and behaviours may not be the most appropriate measure of fish passage success. Impoundments upstream of dams can act as ecological traps (Pelicice \& Agostinho, 2008; Pelicice et al., 2015) preventing downstream movement of eggs and larvae necessary to complete fish life cycles. Providing effective upstream passage for adults past dams, therefore, acts as a population sink with negative consequences for the long-term sustainability of fish populations (Pelicice \& Agostinho, 2008). Likewise, in New Zealand, juvenile eels (Anguilla dieffenbachii and A. australis) are regularly transferred upstream of hydropower dams to seed upstream populations, but in most cases there is no, or only very limited, facility for subsequent downstream passage of migrant adults through the dams (Jellyman, 2007). Thus, while they do support fisheries, the long-term value to biodiversity conservation may be questionable. Harris et al. (2016), in a review of barrier mitigation efforts in Australia, also highlight the challenges of catering for a mixture of life-history strategies across freshwater fish communities. They propose that there is a need for river basin-scale management strategies that integrate fishway construction, where appropriate, with other approaches such as barrier removal, improved barrier management, environmental flow provision and strategic prioritisation of mitigation efforts. Furthermore, they also support the idea of broader definitions of fishway success and the need for performance to be assessed against predetermined, comprehensive biological criteria including considerations for cumulative 
effects of multiple barriers. The concept of river basin-scale decision making is also emphasised by Winemiller et al. (2016), who suggest we should strive for more integrated and strategic planning of dams that also takes in to account the cumulative effects of multiple structures on hydrology, sediment dynamics, ecosystem productivity, fisheries and biodiversity.

We echo these calls for the need to take a step back and consider strategies for managing connectivity at a broader scale, rather than thinking about fish passage on a site-bysite basis in isolation from the wider catchment context, as is commonly done today. Crucial to progressing the fish passage debate is also the need to move beyond the idea that fishways provide a universal solution to mitigating the impacts of instream structures on aquatic communities (Brown et al., 2013; Kemp, 2016). While we do not disagree with the view of Williams, Armstrong, Katapodis, Larinier, \& Travade (2012) that with sufficient investment in ecohydraulic research effective fishways can be engineered, this belief is still predicated on the anthropocentric impair-then-repair approach, and the assumption that providing fish passage at instream infrastructure is inherently good. Additionally, as Kemp (2016) rightly identifies, in many cases and for the majority of species, knowledge is currently far short of being able to develop such technical solutions (e.g. Wilkes et al., 2018), and that sufficient funding and many years of research will be required to fill those knowledge gaps. In the meantime, we propose some recommendations to address the biases currently limiting fish passage in Table 2. We emphasise in the first instance the need to avoid creating new barriers. New structures should be planned in a catchment or regional context and, where deemed necessary from a socioeconomic perspective, be built in a manner that avoids or minimises impacts on fish movements. We recognise that remediation of existing structures can be more challenging due to existing site constraints and legacies, but we highlight the 
need for removal to become the go-to option and for a more holistic approach to finding

547 solutions where removal is not practicable.

548

\section{Conclusion}

550 In river ecosystems, fragmentation is a key driver of the Anthropocene biodiversity crisis

551 (Meybeck, 2003), raising alarm bells in the midst of a global boom in dam building (Zarfl et al., 2015). Paradoxically, because biodiversity and ecosystem function are inextricably linked, river basin development aimed at supporting food, energy and water security may actually be having the opposite effect. The uncritical application of fishway technology has traditionally been the measure of choice to mitigate connectivity losses, but it is increasingly seen as a technology in decline. As is typically the case when a solution is not working, the reasons why lie in its historical development. Early fishways were conceived in response to the collapse of salmonid stocks due to a proliferation of migration barriers in Northern Europe. The migratory characteristics of salmonid species meant that application of traditional, deterministic engineering approaches came to dominate, specifically focusing on upstream migration. With the realisation that connectivity is important for taxa other than salmonids, and the sharp increase in dam building outside of the temperate Northern Hemisphere, came the erroneous assumption that salmonid-type fishways would work everywhere for all species. Evidence to the contrary is now overwhelming but, as is usual with a paradigm shift, the response lags behind. However, the debate is rapidly intensifying, supported by the emergence of revised thinking, particularly from outside of the temperate

567 Northern Hemisphere, and by increasingly interdisciplinary training of practitioners. We have attempted to contribute to this debate in the hope that continued discourse will lead to better conservation of fish biodiversity in the near future. We have highlighted examples that we 
believe represent progress and proposed guiding principles for helping to advance the fish passage discipline. However, if we fail to address these issues, we will never reverse the loss.

\section{Acknowledgements}

This contribution was funded by the European Union AMBER project (Adaptive

Management of Barriers in European Rivers, \#689682), the Danish Fishing License Funds and the New Zealand Ministry for Business, Innovation and Employment contract

C01X1615. It was further supported by the European Commission through the Marie

Sklodowska-Curie action, 'Knowledge Exchange for Efficient Passage of Fish in the

Southern Hemisphere' (RISE-2015-690857-KEEPFISH).

\section{References}

Aarestrup, K., Lucas, M. C., \& Hansen, J. A. (2003). Efficiency of a nature-like bypass channel for sea trout (Salmo trutta) ascending a small Danish stream studied by PIT telemetry. Ecology of Freshwater Fish, 12, 160-168.

Aarestrup, K., Birnie-Gauvin, K., \& Larsen, M.H. (2018) Another paradigm lost? Autumn downstream migration of juvenile brown trout: Evidence for a presmolt migration. Ecology of Freshwater Fish, 27, 513-516.

Agostinho, C.S., Pereira, C.R., Oliveira, R.J.D., Freitas, I.S., \& Marques, E.E. (2007) Movements through a fish ladder: temporal patterns and motivations to move upstream. Neotropical Ichthyology, 5, 161-167.

Amtstaetter, F., O’Connor, J., Borg, D., Stuart, I., \& Moloney, P. (2017) Remediation of upstream passage for migrating Galaxias (Family: Galaxiidae) through a pipe culvert. Fisheries Management and Ecology, 24, 186-192.

Arnekleiv, J.V., Kraabøl, M., \& Museth, J. (2007). Efforts to aid downstream migration brown trout (Salmo trutta L.) kelts and smolts passing a hydroelectric dam and a spillway. Hydrobiologia, 582, 5-15.

Baird, I.G., (2006) Probarbus jullieni and Probarbus labeamajor: the management and conservation of two of the largest fish species in the Mekong River in southern Laos. Aquatic Conservation: Marine and Freshwater Ecosystems, 16, 517-532.

Baker, C.F. (2003) Effect of fall height and notch shape on the passage of inanga (Galaxias maculatus) and common bullies (Gobiomorphus cotidianus) over an experimental weir. New Zealand Journal of Marine and Freshwater Research, 37, 283-290.

Baker, C.F., Reeve, K., Baars, D., Jellyman, D., \& Franklin, P. (2017) Efficacy of 12-mm half-duplex passive integrated transponder tags in monitoring fish movements through stationary antenna systems. North American Journal of Fisheries Management, 37, 1289-1298.

Bannon, H.J., \& Ling, N. (2003) Running the unseen, lowland gauntlet: Compounding effects of temperature, hypoxia and exercise for diadromous fishes. In Rupp, G., \& White, M.D. (Eds.), Seventh International Symposium on Fish Physiology, Toxicology and Water Quality (pp. 207-218), Tallinn, Estonia: USEPA. 
Barnard, R.J., Yokers, S., Nagygyor, A., \& Quinn, T. (2015). An evaluation of the stream simulation culvert design method in Washington State. River Research and Applications, 31, 1376-1387.

Beamish, F.W.H. (1978) Swimming capacity. In Hoar, W.S., \& Randall, D.J. (Eds), Fish physiology VII (pp. 101-187), New York, USA: Academic Press.

Bergkamp, G., McCartney, M., Dugan, P., McNeely, J., \& Acreman, M.C. (2000). Dams, ecosystem functions and environmental restoration. Cape Town, World Commission on Dams.

Birnie-Gauvin, K., Aarestrup, K., Riis, T.M.O., Jepsen, N., \& Koed, A. (2017). Shining a light on the loss of rheophilic fish habitat in lowland rivers as a forgotten consequence of barriers, and its implications for management. Aquatic Conservation: Marine and Freshwater Ecosystems. DOI: 10.1002/aqc.2795.

Birnie-Gauvin, K., Tummers, J.S., Lucas, M.C., \& Aarestrup, K. (2017) Adaptive management in the context of barriers in European freshwater ecosystems. Journal of Environmental Management, 204, 436-431.

Birnie-Gauvin, K., Larsen, M.H., Nielsen, J., \& Aarestrup, K. (2017) 30 years of data reveal a dramatic increase in abundance of brown trout following the removal of a small hydrodam. Journal of Environmental Management, 204, 467-471.

Birnie-Gauvin, K., Candee, M.M., Baktoft, H., Larsen, M.H., Koed, A., \& Aarestrup, K. (in press). River connectivity reestablished: effects and implications of six weir removals on brown trout smolt migration. River Research and Applications.

Birnie-Gauvin, K., Larsen, M.H., Thomassen, S.T., \& Aarestrup, K. (2018) Testing three common stocking methods: differences in smolt size, migration rate and timing of two strains of stocked Atlantic salmon (Salmo salar). Aquaculture, 483, 163-168.

Boys, C.A., Kroon, F.J., Glasby, T.M., \& Wilkinson, K. (2012) Improved fish and crustacean passage in tidal creeks following floodgate remediation. Journal of Applied Ecology, 49, 223-233.

Branco, P., Amaral, S.D., Ferreira, M.T., \& Santos, J,M. (2017) Do small barriers affect the movement of freshwater fish by increasing residency? Science of The Total Environment, 581, 486-494.

Brauer, C.J., Hammer, M.P. \& Beheregaray, L.B. (2016) Riverscape genomics of a threatened fish across a hydroclimatically heterogeneous river basin. Molecular Ecology, 25, 5093-5113.

Brown, J.J., Limburg, K.E., Waldman, J.R., Stephenson, K., Glenn, E.P., Juanes, F., \& Jordaan, A. (2013) Fish and hydropower on the U.S. Atlantic coast: failed fisheries policies from half-way technologies. Conservation Letters, 6, 280-286.

Bunn, S.E. \& Arthington, A.H. (2002). Basic principles and ecological consequences of altered flow regimes for aquatic biodiversity. Environmental Management, 30, 492-507.

Bunt, C.M., Castro-Santos, T., \& Haro, A. (2012) Performance of fish passage structures at upstream barriers to migration. River Research and Applications, 28, 457-478.

Bunt, C.M., Castro-Santos, T., \& Haro, A. (2016) Reinforcement and validation of the analyses and conclusions related to fishway evaluation data from Bunt et al.: 'Performance of fish passage structures at upstream barriers to migration'. River Research and Applications, 32, 2125-2137.

Cooke, S.J., Bunt, C.M., Hamilton, S.J., Jennings, C.A., Pearson, M.P., Cooperman, M.S., \& Markle, D.F. (2005) Threats, conservation strategies, and prognosis for suckers (Catostomidae) in North America: insights from regional case studies of a diverse family of non-game fishes. Biological Conservation, 121, 317-331.

Colavecchia, M., Katopodis, C., Goosney, R., Scruton, D.A., \& McKinley, R.S. (1998). Measurement of burst swimming performance in wild Atlantic salmon (Salmo salar L.) 
using digital telemetry. Regulated Rivers: Research \& Management, 14, 41-51.

David, B.O., \& Hamer, M.P. (2012). Remediation of a perched stream culvert with ropes improves fish passage. Marine and Freshwater Research, 63, 440-449.

David, B.O., Tonkin, J.D., Taipeti, K.W.T., \& Hokianga, H.T. (2014) Learning the ropes: Mussel spat ropes improve fish and shrimp passage through culverts. Journal of Applied Ecology, 51, 214-223.

Dudgeon, D., Arthington, A.H., Gessner, M.O., Kawabata, Z.-I., Knowler, D.J., Lévêque, C., ... Sullivan, C.A. (2006) Freshwater biodiversity: importance, threats, status and conservation challenges. Biological Reviews, 81, 163-182.

Ead, S.A., Rajaratnam, N., \& Katopodis, C. (2002). Generalized Study of Hydraulics of Culvert Fishways. Journal of Hydraulic Engineering, 128, 1018-1022.

Erkinaro, J., Erkinaro, H., \& Niemelä, E. (2017) Road culvert restoration expands the habitat connectivity and production area of juvenile Atlantic salmon in a large subarctic river system. Fisheries Management and Ecology, 24, 73-81.

Falke, J.A., Fausch, K.D., Bestgen, K.R., \& Bailey, L.L. (2010). Spawning phenology and habitat use in a Great Plains, USA, stream fish assemblage: an occupancy estimation approach. Canadian Journal of Fisheries and Aquatic Sciences, 67, 1942-1956.

Forest Service Stream-Simulation Working Group. (2008) Stream simulation: An ecological approach to providing passage for aquatic organisms at road-stream crossings. San Dimas, CA: U.S. Department of Agriculture.

Francis, F. (1870) Reports on salmon ladders: with original drawings, plans and sections. Horace Cox, London.

Franklin, P.A., \& Bartels, B. (2012) Restoring connectivity for migratory native fish in a New Zealand stream: Effectiveness of retrofitting a pipe culvert. Aquatic Conservation: Marine and Freshwater Ecosystems, 22, 489-497.

Franklin, P.A., \& Hodges, M. (2015) Modified tide gate management for enhancing instream habitat for native fish upstream of the saline limit. Ecological Engineering, 81, 233-242.

Froese, R., \& Pauly, D. (Eds.) (2016) FishBase. www.fishbase.org

Gangloff, M. M. (2013). Taxonomic and ecological tradeoffs associated with small dam removals. Aquatic Conservation: Marine and Freshwater Ecosystems, 23, 475-480.

Garcia-Moreno, J., Harrison, I.J., Dudgeon, D., Clausnitzer, V., Darwall, W., Farrell, T., ... Tubbs, N. (2014) Sustaining freshwater biodiversity in the Anthropocene. In Bhaduri, A., Bogardi, J., Leentvaar, J., \& Marx, S. (Eds.), The Global Water System in the Anthropocene (pp. 247-270). Springer, Cham: Springer International Publishing.

Gibson, R.J., Haedrich, R.L., \& Wernerheim, C.M. (2011) Loss of Fish Habitat as a Consequence of Inappropriately Constructed Stream Crossings. Fisheries, 30, 10-17.

Gillespie, N., Unthank, A., Campbell, L., Anderson, P., Gubernick, R., Weinhold, M., ... Kirn, R. (2014) Flood effects on road-stream crossing infrastructure: economic and ecological benefits of stream simulation designs. Fisheries, 39, 62-76.

Goerig, E., Bergeron, N.E., \& Castro-Santos, T. (2017) Swimming behaviour and ascent paths of brook trout in a corrugated culvert. River Research and Applications, 33, 14631471.

Hari, R.E., Livingstone, D.M., Siber, R., Burkhardt-Holm, P., \& Guttinger, H. (2006) Consequences of climatic change for water temperature and brown trout populations in Alpine rivers and streams. Global Change Biology, 12, 10-26.

Haro, A., Castro-Santos, T., Noreika, J., \& Odeh, M. (2004) Swimming performance of upstream migrant fishes in open-channel flow: a new approach to predicting passage through velocity barriers. Canadian Journal of Fisheries and Aquatic Sciences, 61, 1590-1601.

Harris, J.H., Kingsford, R.T., Peirson, W., \& Baumgartner, L.J. (2016) Mitigating the effects 
of barriers to freshwater fish migrations: the Australian experience. Marine and Freshwater Research, 10, 687-696.

Hitt, N.P., Eyler, S., \& Wofford, J.E.B. (2012) Dam removal increases American eel abundance in distant headwater streams. Transactions of the American Fisheries Society, $141,1171-1179$.

Hogg, R., Coghlan, S.M., \& Zydlewski, J. (2013) Anadromous sea lampreys recolonize a Maine coastal river tributary after dam removal. Transactions of the American Fisheries Society, 142, 1381-1394.

Jellyman, D.J. (2007) Status of New Zealand fresh-water eel stocks and management initiatives. ICES Journal of Marine Science, 64, 1379-1386.

Jepsen, N., Aarestrup, K., Økland, F., \& Rasmussen, G. (1998) Survival of radiotagged Atlantic salmon (Salmo salar L.)-and trout (Salmo trutta L.) smolts passing a reservoir during seaward migration. Hydrobiologia, 371, 347-353.

Jepsen, N., \& Berg, S. (2002) The use of winter refuges by roach tagged with miniature radio transmitters. In Thorstad, E.B., Fleming, I.A., \& Næsje, T.F. (Eds.), Aquatic Telemetry (pp. 167-173). Springer: Netherlands.

Katopodis, C., \& Williams, J.G. (2012) The development of fish passage research in a historical context. Ecological Engineering, 48, 8-18.

Kemp, P.S. (2016) Meta-analyses, metrics and motivation: mixed messages in the fish passage debate. River Research and Applications, 32, 2116-2124.

Link, O., \& Habit, E. (2015) Requirements and boundary conditions for fish passes of nonsport fish species based on Chilean experiences. Reviews in Environmental Science and Bio/Technology, 14, 9-21.

Link, O., Sanhueza, C., Arriagada, P., Brevis, W., Laborde, A., González, A., ... Habit, E. (2017) The fish Strouhal number as a criterion for hydraulic fishway design. Ecological Engineering, 103, 118-126.

Lira, N.A., Pompeu, P.S., Agostinho, C.S., Agostinho, A.A., Arcifa, M.S., \& Pelicice, F.M. (2017) Fish passages in South America: an overview of studied facilities and research effort. Neotropical Ichthyology, 15, e160139.

Lucas, M.C., Bubb, D.H., Jang, M.-H., Ha, K., \& Masters, J.E.G. (2009) Availability of and access to critical habitats in regulated rivers: effects of low-head barriers on threatened lampreys. Freshwater Biology, 54, 621-634.

Mallen-Cooper, M., \& Brand, D.A. (2007) Non-salmonids in a salmonid fishway: what do 50 years of data tell us about past and future fish passage? Fisheries Management and Ecology, 14, 319-332.

McCormick, S.D., Lerner, D.T., Monette, M.Y., Nieves-Puigdoller, K., Kelly, J.T., \& Björnsson, B.T. (2009) Taking it with you when you go: How perturbations to the freshwater environment, including temperature, dams, and contaminants, affect marine survival of salmon. American Fisheries Society Symposium, 69, 195-214.

McLaughlin, R.L., Smyth, E.R.B., Castro-Santos, T., Jones, M.L., Koops, M.A., Pratt, T.C., \& Vélez-Espino, L.-A. (2013) Unintended consequences and trade-offs of fish passage. Fish and Fisheries, 14, 580-604.

Meybeck, M. (2003) Global analysis of river systems: from Earth system controls to Anthropocene syndromes. Philosophical transactions of the Royal Society of London. Series B, Biological Sciences, 358, 1935-1955.

Morita, K., \& Yamamoto, S. (2002). Effects of habitat fragmentation by damming on the persistence of stream-dwelling charr populations. Conservation Biology, 16, 1318-1323.

Nehlsen, W., Williams, J.E., \& Lichatowich, J.A. (1991) Pacific salmon at the crossroads: stocks at risk from California, Oregon, Idaho, and Washington. Fisheries, 16, 4-21.

Nieminen, E., Hyytiäinen, K., \& Lindroos, M. (2017) Economic and policy considerations 
regarding hydropower and migratory fish. Fish and Fisheries, 18, 54-78.

Nikora, V.I., Aberle, J., Biggs, B.J.F., Jowett, I.G., \& Sykes, J.R.E. (2003). Effects of fish size, time-to-fatigue and turbulence on swimming performance: a case study of Galaxias maculatus. Journal of Fish Biology, 63, 1365-1382.

Noonan, M.J., Grant, J.W.A., \& Jackson, C.D. (2012) A quantitative assessment of fish passage efficiency. Fish and Fisheries, 13, 450-464.

O’Connor, J.E., Duda, J.J., \& Grant, G.E. (2015) Ecology. 1000 dams down and counting. Science, 348, 496-497.

Peake, S. (2004) An evaluation of the use of critical swimming speed for determination of culvert water velocity criteria for smallmouth bass. Transactions of the American Fisheries Society, 133, 1472-1479.

Pelicice, F.M., \& Agostinho, A.A. (2008) Fish-passage facilities as ecological traps in large Neotropical rivers. Conservation Biology, 22, 180-188.

Pelicice, F.M., Pompeu, P.S., \& Agostinho, A.A. (2015) Large reservoirs as ecological barriers to downstream movements of Neotropical migratory fish. Fish and Fisheries, 16, 697-715.

Pelicice, F.M., Azevedo-Santos, V.M., Vitule, J.R., Orsi, M.L., Lima Junior, D.P., Magalhães, A.L., ... Agostinho, A.A. (2017). Neotropical freshwater fishes imperilled by unsustainable policies. Fish and Fisheries, 18, 1119-1133.

Perkin, J.S., Gido, K.B., Cooper, A.R., Turner, T.F., Osborne, M.J., Johnson, E.R. \& Mayes, K.B. (2015) Fragmentation and dewatering transform Great Plains stream fish communities. Ecological Monographs, 85, 73-92.

Plew, D.R., Nikora, V.I., Larned, S.T., Sykes, J.R. \& Cooper, G.G. (2007). Fish swimming speed variability at constant flow: Galaxias maculatus. New Zealand Journal of Marine and Freshwater Research, 41, 185-195.

Poff, N.L. (2014) Rivers of the anthropocene? Frontiers in Ecology and the Environment, 12, 427.

Pompeu, P.S., Agostinho, A.A., \& Pelicice, F.M. (2012) Existing and future challenges: the concept of successful fish passage in South America. River Research and Applications, 28, 504-512.

Porcher, J.P., \& Travade, F. (1992) Les dispositifs de franchissement : bases biologiques, limites et rappels réglementaires. Bulletin Français de la Pêche et de la Pisciculture, 326-327, 5-14.

Radinger, J., \& Wolter, C. (2014) Patterns and predictors of fish dispersal in rivers. Fish and Fisheries, 15, 456-473.

Rajaratnam, N., Katopodis, C., \& Lodewyk, S. (1988) Hydraulics of offset baffle culvert fishways. Canadian Journal of Civil Engineering, 15, 1043-1051.

Raeymaekers, J.A., Maes, G.E., Geldof, S., Hontis, I., Nackaerts, K. \& Volckaert, F.A. (2008) Modeling genetic connectivity in sticklebacks as a guideline for river restoration. Evolutionary Applications, 1, 475-488.

Rodgers, E.M., Cramp, R.L., Gordos, M., Weier, A., Fairfall, S., Riches, M., \& Franklin, C.E. (2014). Facilitating upstream passage of small-bodied fishes: linking the thermal dependence of swimming ability to culvert design. Marine and Freshwater Research, 65, 710-719.

Roscoe, D.W., \& Hinch, S.G. (2010) Effectiveness monitoring of fish passage facilities: historical trends, geographic patterns and future directions. Fish and Fisheries, 11, 12 33.

Santos, H., Pompeu, P.S., \& Martinez, C.B. (2007). Swimming performance of the migratory Neotropical fish Leporinus reinhardti (Characiformes: Anostomidae). Neotropical Ichthyology, 5, 139-146. 
Schlosser, I.J., \& Angermeier, P.L. (1995) Spatial variation in demographic processes in lotic fishes: Conceptual models, empirical evidence, and implications for conservation. American Fisheries Society Symposium, 17 360-370.

Silva, A.T., Lucas, M.C., Castro-Santos, T., Katapodis, C., Baumgartner, L.J., Thiem, J.D., ... Cooke, S.J. (2018) The future of fish passage science, engineering, and practice. Fish and Fisheries. 19, 340-362.

Starrs, D., Ebner, B.C., Lintermans, M., \& Fulton, C.J. (2011). Using sprint swimming performance to predict upstream passage of the endangered Macquarie perch in a highly regulated river. Fisheries Management and Ecology, 18, 360-374.

Svendsen, J. C., Eskesen, A. O., Aarestrup, K., Koed, A., \& Jordan, A. D. (2007) Evidence for non-random spatial positioning of migrating smolts (Salmonidae) in a small lowland stream. Freshwater Biology, 52, 1147-1158.

Timm, A., Higgins, D., Stanovick, J., Kolka, R., \& Eggert, S. (2017). Quantifying fish habitat associated with stream simulation design culverts in Northern Wisconsin. River Research and Applications, 33, 567-577.

Tockner, K., Schiemer, F., \& Ward, J.V. (1998) Conservation by restoration: the management concept for a river-floodplain system on the Danube River in Austria. Aquatic Conservation: Marine and Freshwater Ecosystems, 8, 71-86.

Tudorache, C., Viaene, P., Blust, R., Vereecken, H., \& De Boeck, G. (2008). A comparison of swimming capacity and energy use in seven European freshwater fish species. Ecology of Freshwater Fish, 17, 284-291.

Vignieri, S. (2014) Vanishing fauna. Introduction. Science, 345, 392-395.

Vörösmarty, C.J., McIntyre, P.B., Gessner, M.O., Dudgeon, D., Prusevich, A., Green, P., ...Davies, P.M. (2010) Global threats to human water security and river biodiversity. Nature, 467, 555-561.

Vörösmarty, C.J., Pahl-Wostl, C., Bunn, S.E., \& Lawford, R. (2013) Global water, the anthropocene and the transformation of a science. Current Opinion in Environmental Sustainability, 5, 539-550.

Vrieze, L.A., Bjerselius, R., \&Sorensen, P.W. (2010) Importance of the olfactory sense to migratory sea lampreys Petromyzon marinus seeking riverine spawning habitat. Journal of Fish Biology, 76, 949-964.

Wan, Q., Fan, S., \& Li, Y. (2003) The loss of diversity in Dabry's Sturgeon (Acipenser dabryanus Dumeril) as revealed by DNA fingerprinting. Aquatic Conservation: Marine and Freshwater Ecosystems, 13, 225-231.

Wei, Q., Ke, F., Zhang, J., Zhuang, P., Lou, J., Zhou, R., \& Wang, W. (1997) Biology, fisheries, and conservation of freshwater biodiversity 181 sturgeons and paddlefish in China. Environmental Biology of Fishes, 48, 241-255.

Wei, Q., He, D., Yang, D., Zhang, W., \& Li, L. (2004) Status of sturgeon aquaculture and sturgeon trade in China: a review based on two recent nationwide surveys. Journal of Applied Ichthyology, 20, 321-332.

Welcomme, R.L. (1985). River fisheries. FAO Fisheries Technical Paper (262), pp 30.

Wheeler, A.P., Angermeier, P.L., \& Rosenberger, A.E. (2005) Impacts of new highways and subsequent landscape urbanization on stream habitat and biota. Reviews in Fisheries Science, 13, 141-164.

Wilkes, M.A., Mckenzie, M., \& Webb, J.A. (2018) Fish passage design for sustainable hydropower in the temperate Southern Hemisphere: an evidence review. Reviews in Fish Biology and Fisheries, 28, 117-135. DOI 10.1007/s11160-017-9496-8.

Wilkes, M.A., Baumgartner, L., Boys, C., Silva, L.G.M., O’Connor, J., Jones, M., Stuart, I., Habit, E., Link, O. \& Webb, J.A. (in press) Fish-Net: Probabilistic models for fishway planning, design and monitoring to support environmentally sustainable hydropower. 
Fish \& Fisheries. doi: 10.1111/faf.12282

Williams, J.G., \& Katopodis, C. (2016). Commentary: Incorrect application of data negates some meta-analysis results in Bunt et al. (2012). River Research and Applications, 32, 2109-2115.

Williams, J.G., Armstrong, G., Katopodis, C., Larinier, M., \& Travade, F. (2012) Thinking like a fish: A key ingredient for development of effective fish passage facilities at river obstructions. River Research and Applications, 28, 407-417.

Winemiller, K.O., McIntyre, P.B., Castello, L., Fluet-Chouinard, E., Giarrizzo, T., Nam, S., ... Sáenz, L. (2016) Balancing hydropower and biodiversity in the Amazon, Congo, and Mekong. Science, 351, 128-9.

Winter, E.R., Tummers, J.S., Aarestrup, K., Baktoft, H., \& Lucas, M.C. (2016) Investigating the phenology of seaward migration of juvenile brown trout (Salmo trutta) in two European populations. Hydrobiologia, 775, 139-151.

Wofford, J.E., Gresswell, R.E. \& Banks, M.A. (2005) Influence of barriers to movement on within-watershed genetic variation of coastal cutthroat trout. Ecological Applications, 15, 628-637.

Yeakley, J.A., Maas-Hebner, K.G., \& Hughes, R.M. (2014). Wild Salmonids in the Urbanizing Pacific Northwest. New York, USA: Springer.

Zarfl, C., Lumsdon, A.E., Berlekamp, J., Tydecks, L., \& Tockner, K. (2015) A global boom in hydropower dam construction. Aquatic Sciences, 77, 161-170. 
Table 1. Examples of fish population declines and local extinctions ascribed to river fragmentation.

\begin{tabular}{|l|l|l|l|}
\hline Species & Location & Fragmentation impacts & References \\
\hline $\begin{array}{l}\text { Atlantic salmon; } \\
\text { Salmo salar }\end{array}$ & $\begin{array}{l}\text { Rhine, Seine and } \\
\text { Garonne basins, } \\
\text { France } \\
\text { Gudenaa River, } \\
\text { Denmark }\end{array}$ & $\begin{array}{l}\text { Disappearance of whole } \\
\text { stocks }\end{array}$ & $\begin{array}{l}\text { Porcher \& } \\
\text { Travade } \\
\text { (1992); } \\
\text { Jepsen et al. } \\
\text { (1998) }\end{array}$ \\
\hline $\begin{array}{l}\text { Pacific salmon; } \\
\text { Oncorhynchus } \\
\text { spp. }\end{array}$ & Pacific Coast, USA & $\begin{array}{l}\text { 101 stocks at high risk of } \\
\text { extinction }\end{array}$ & $\begin{array}{l}\text { Nehlsen, } \\
\text { Williams \& } \\
\text { Lichatowich. } \\
\text { (1991) }\end{array}$ \\
\hline $\begin{array}{l}\text { Whitespotted } \\
\text { char; Salvelinus } \\
\text { leucomaeni }\end{array}$ & Hokkaido, Japan & $\begin{array}{l}\text { Local extinction at 17 sites } \\
\text { upstream of dams }\end{array}$ & $\begin{array}{l}\text { Morita \& } \\
\text { Yamamoto } \\
\text { (2002) }\end{array}$ \\
\hline $\begin{array}{l}\text { Dabry's sturgeon; } \\
\text { Acipenser } \\
\text { dabryanus }\end{array}$ & Yangtze River & $\begin{array}{l}\text { Critically endangered } \\
\text { (possibly extinct) }\end{array}$ & $\begin{array}{l}\text { Wei et al. } \\
\text { (1997, 2004); } \\
\text { Wan, Fan \& } \\
\text { Li (2003) }\end{array}$ \\
\hline $\begin{array}{l}\text { Spotted sorubim; } \\
\text { Pseudoplatystoma } \\
\text { coruscans }\end{array}$ & São Paulo state, Brazil & $\begin{array}{l}\text { Rapid local extinction after } \\
\text { dam construction }\end{array}$ & $\begin{array}{l}\text { Welcomme } \\
\text { (1985) }\end{array}$ \\
\hline $\begin{array}{l}\text { Jullien's golden } \\
\text { carp; Probarbus } \\
\text { jullieni }\end{array}$ & Northern Malaysia & $\begin{array}{l}\text { Possibly local extinction } \\
\text { (Pahang River) and } \\
\text { significant population } \\
\text { decline (Perak River) }\end{array}$ & $\begin{array}{l}\text { Baird (2006); } \\
\text { Dudgeon et al. } \\
\text { (2006) }\end{array}$ \\
\hline
\end{tabular}


Table 2. Recommendations to address biases in fish passage research and applications.

1. Avoid building new barriers whenever possible; if unavoidable, build the dam/weir/culvert such that it is not a barrier

2. First choice should always be to remove existing structures rather than to engineer a solution

3. Reconsider removing barrier (\#2)

4. Recognise and embrace diversity of fish movement ecology

5. Integrate natural variation and build in uncertainty to designs

6. Use a more holistic approach including the consideration of geomorphic and hydrological processes

7. Stop recommending absolute design criteria from laboratory swimming tests. Laboratory experiments are excellent tools for comparative studies, but lack biological and environmental realism

8. Use an evidence-based approach 


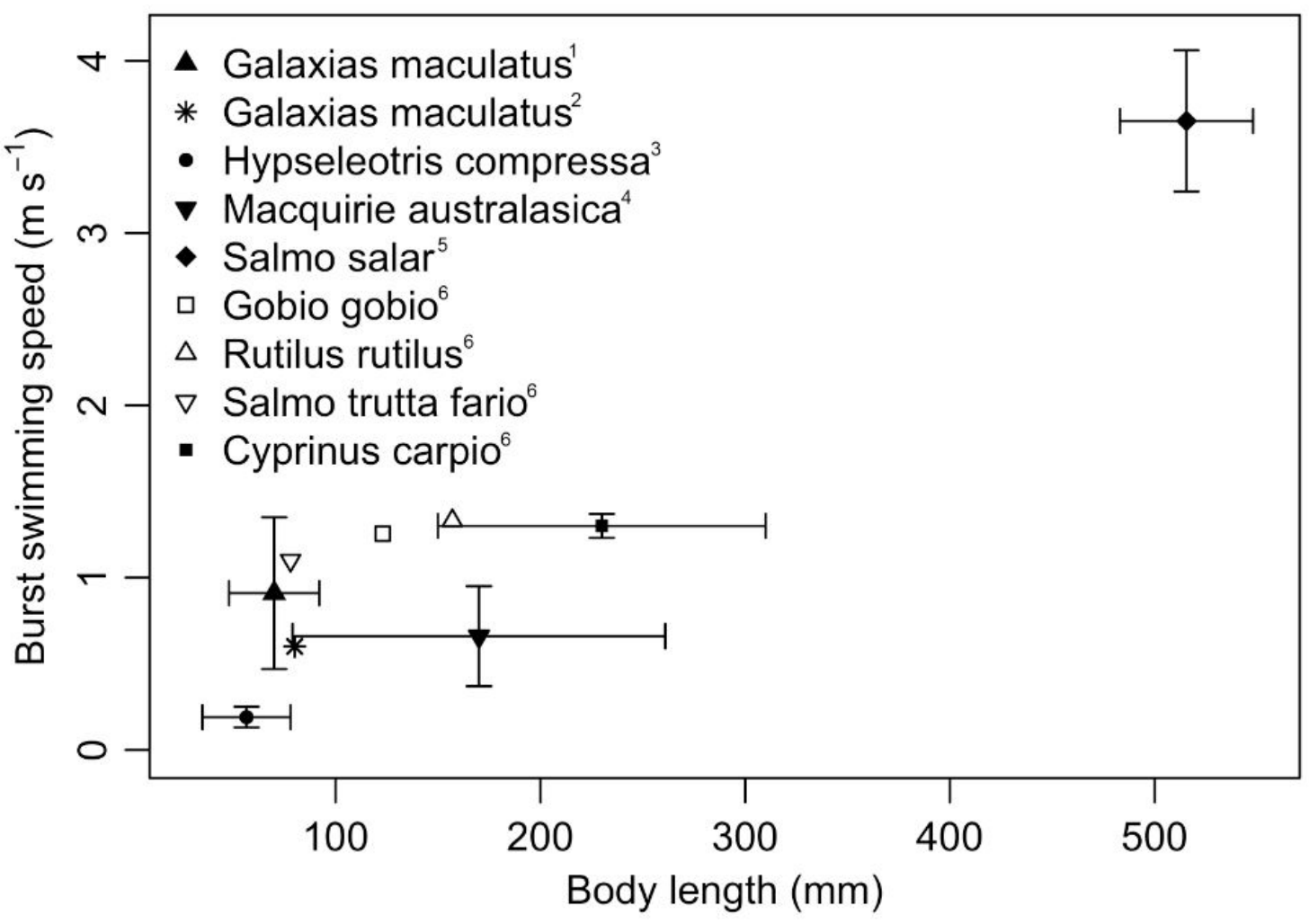

953

954 Figure 1. Burst swimming speeds (the maximum swimming velocity that a fish is capable of 955 sustaining for up to $20 \mathrm{~s}$ ) of salmonids and other migratory fish with characteristic body 956 lengths at the time of upstream migration. All species listed are defined as diadromous or 957 potamodromous in FishBase (Froese \& Pauly, 2016). All studies listed sampled burst 958 swimming speeds in laboratory flumes. Symbols show modes. Whiskers show range from 959 selected studies to demonstrate population-level variation. Examples cited: ${ }^{1}$ Nikora, Aberle, 960 Biggs, Jowett \& Sykes. (2003); ${ }^{2}$ Plew, Nikora, Larned, Sykes, \& Cooper (2007); ${ }^{3}$ Rodgers et 961 al. (2014); ${ }^{4}$ Starrs, Ebner, Lintermans \& Fulton (2011); ${ }^{5}$ Colavecchia, Katopodis, Goosney, 962 Scruton \& McKinley (1998); and ${ }^{6}$ Tudorache, Viaene, Blust, Vereecken \& De Boeck (2008). 